\title{
Sorafenib decreases proliferation and induces apoptosis of prostate cancer cells by inhibition of the androgen receptor and Akt signaling pathways
}

\author{
Su Jung Oh, Holger H H Erb, Alfred Hobisch ${ }^{1}$, Frédéric R Santer* and \\ Zoran Culig*
}

Division of Experimental Urology, Department of Urology, Innsbruck Medical University, Anichstrasse 35, A-6020 Innsbruck, Austria ${ }^{1}$ Department of Urology, General Hospital Feldkirch, Carinagasse 35, A-6800 Feldkirch, Austria

(Correspondence should be addressed to Z Culig; Email: zoran.culig @i-med.ac.at; F R Santer; Email: frederic.santer@i-med.ac.at) *(F R Santer and Z Culig joint senior authors)

\begin{abstract}
Antihormonal and chemotherapy are standard treatments for nonorgan-confined prostate cancer. The effectivity of these therapies is limited and the development of alternative approaches is necessary. In the present study, we report on the use of the multikinase inhibitor sorafenib in a panel of prostate cancer cell lines and their derivatives which mimic endocrine and chemotherapy resistance. ${ }^{3} \mathrm{H}$-thymidine incorporation assays revealed that sorafenib causes a dose-dependent inhibition of proliferation of all cell lines associated with downregulation of cyclin-dependent kinase 2 and cyclin D1 expression. Apoptosis was induced at $2 \mu \mathrm{M}$ of sorafenib in androgen-sensitive cells, whereas a higher dose of the drug was needed in castration-resistant cell lines. Sorafenib stimulated apoptosis in prostate cancer cell lines through downregulation of myeloid cell leukemia-1 (MCL-1) expression and Akt phosphorylation. Although concentrations of sorafenib required for the antitumor effect in therapy-resistant sublines were higher than those needed in parental cells, the drug showed efficacy in cells which became resistant to bicalutamide and docetaxel respectively. Most interestingly, we show that sorafenib has an inhibitory effect on androgen receptor (AR) and prostate-specific antigen expression. In cells in which AR expression was downregulated by short interfering RNA, the treatment with sorafenib increased apoptosis in an additive manner. In summary, the results of the present study indicate that there is a potential to use sorafenib in prostate cancers as an adjuvant therapy option to current androgen ablation treatments, but also in progressed prostate cancers that become unresponsive to standard therapies.
\end{abstract}

Endocrine-Related Cancer (2012) 19 305-319

\section{Introduction}

Prostate cancer is the most common malignancy in Western countries and the second leading cause of cancer-related deaths in males (Jemal et al. 2010). Patients diagnosed with localized disease can be cured by either surgery or radiation therapy. In contrast, advanced stages of the tumor are subjected to androgen ablation treatment in order to reduce the tumor-promoting effect of androgens. Standard therapy approaches include administration of $\mathrm{LH}$ releasing hormone analogs, nonsteroidal antiandrogens (e.g. bicalutamide), or surgical castration. However, androgen-ablated tumors eventually develop resistance to this therapy and progress toward castration-resistant prostate cancer (CRPC), for which only palliative treatment is available. Androgen receptor (AR) was shown to play a critical role in progression of prostate cancer (Grossmann et al. 2001). Activated AR interacts with androgen response elements in the promoters of target genes including prostate-specific antigen (PSA), thereby regulating their transcription. PSA is the most frequently used marker for monitoring response to 
prostate cancer treatment. Chemotherapy for prostate cancer has been used for a number of years, however only limited improvement in survival was observed in CRPC with docetaxel-based therapies (Tannock et al. 2004). Nevertheless, apart from a relatively short extension of survival, $\sim 50 \%$ of patients initially do not respond to docetaxel treatment and are exposed to significant toxicity. Therefore, novel targeted approaches are in need to optimize the currently available therapies for patients with androgen-sensitive and CRPC.

One aim of therapies for various cancers including that of the prostate is to increase the percentage of tumor cells undergoing apoptosis. Increased expression of endogenous inhibitors of programmed cell death is one of the reasons for the development of therapy resistance. One of these inhibitors is myeloid cell leukemia-1 (MCL-1), an antiapoptotic member of the Bcl-2 family, which was originally identified as an early gene induced during differentiation of ML-1 myeloid leukemia cells (Kozopas et al. 1993). MCL-1 is overexpressed in various human malignancies and has been implicated in resistance to anticancer drugs (Craig 2002). Elevated expression of MCL-1 in prostate cancer tissue compared to normal or hyperplastic tissue or prostate intraepithelial neoplasia (Krajewska et al. 1996) suggests an involvement of this protein in tumor initiation and progression. Previously, we demonstrated the importance of MCL-1 in mediating the prosurvival activity of interleukin 6 (IL6) in prostate cancer (Cavarretta et al. 2007). In view of its active role in protecting prostate cancer cells from induction of apoptosis (Cavarretta et al. 2007), targeting MCL-1 could be considered a valid therapeutic approach.

Another potential therapy target is Akt (protein kinase B), a serine-threonine protein kinase, which plays a central role in phosphoinositide-3-kinasemediated signaling. Its activation has been implicated in prostate cancer cell survival as well as in progression to castration resistance and refractoriness to chemotherapy (Nesterov et al. 2001). Akt is frequently activated in advanced prostate cancer due to deletion or mutation of the PTEN tumor suppressor gene (Sircar et al. 2009). In clinical and preclinical studies, overexpression and activation of Akt have been associated with high preoperative levels of PSA, higher Gleason grades, shorter relapses, and resistance to treatment (Sircar et al. 2009). Activated Akt phosphorylates and thereby inactivates its downstream target glycogen synthase kinase- $3 \beta$ (GSK-3 $\beta$ ). Consequently, GSK-3 $\beta$-mediated phosphorylation of MCL-1 promotes its binding to the E3 ligase $\beta$-TrCP and degradation of MCL-1 by the proteasome (Ding et al. 2007). Furthermore, it has recently been reported that Akt activity can positively regulate AR protein levels (Ha et al. 2011).

Sorafenib (Nexavar, BAY 43-9006) is an oral multikinase inhibitor that was initially developed in an attempt to block Raf kinase, a well-studied serinethreonine kinase regulating cell survival (Wilhelm et al. 2004). It was revealed that sorafenib also targets a number of receptor tyrosine kinases involved in neoangiogenesis including vascular endothelial growth factor receptor, platelet-derived growth factor receptor, FLT3, Ret, and c-Kit (Wilhelm et al. 2004). Moreover, sorafenib was found to induce apoptosis in several human cancer cell lines by downregulating the expression levels of MCL-1 (Rahmani et al. 2005). Sorafenib has shown promising preclinical activity against a variety of tumor types and is approved for the treatment of hepatocellular and renal cell carcinoma (Kane et al. 2006, Lang 2008). In prostate cancer, it was shown that sorafenib treatment has a positive outcome in clinical studies in combination with antiangiogenic agents in CRPC (Steinbild et al. 2007, Chi et al. 2008, Dahut et al. 2008). Although sorafenib is undergoing phase II clinical evaluation for treatment of prostate cancer, molecular events following inhibition of its targets and regulation of the apoptotic pathways have not been studied systematically. We also hypothesized that sorafenib has a potential in the treatment of endocrine- and chemotherapy-resistant prostate cancer.

In this study, we demonstrate that sorafenib exerts antiproliferative and proapoptotic activities in human prostate cancer cells by targeting several regulators of cell cycle progression and survival. We also evaluated the antitumor efficacy of sorafenib in bicalutamideand docetaxel-resistant cell lines in order to test the anticancer potential of sorafenib in therapy-resistant prostate cancer.

\section{Materials and methods}

\section{Cell lines}

Prostate cancer cells PC3, LNCaP, and 22Rv1 were obtained from ATCC (Rockville, MD, USA). Cell line authenticity was confirmed by short tandem repeat analysis. The LNCaP subline LNCaP-IL6+ was derived in the presence of IL6, as described elsewhere (Hobisch et al. 2001). The therapy-resistant model LNCaP-Bic was obtained by long-term treatment of LNCaP cells with $10 \mathrm{pM}$ R1881 and $1 \mu \mathrm{M}$ bicalutamide (Hobisch et al. 2006). The LNCaP-abl subline 
was described previously (Culig et al. 1999). PC3-DR cells were established by continuously treating PC3 cells in a dose escalation manner with docetaxel until reaching a concentration of $12.5 \mathrm{nM}$ in analogy to Patterson et al. (2006). PC3 cells were cultured in RPMI 1640 containing 10\% FCS, 1\% antibiotics, and glutaMax. For LNCaP and 22Rv1 cell lines, media were additionally supplemented with $1 \mathrm{mM}$ sodium pyruvate, $4.5 \mathrm{~g} / \mathrm{l}$ glucose, and $10 \mathrm{mM}$ HEPES buffer (pH 7.2). LNCaP-IL6 + cells were maintained in the presence of $5 \mathrm{ng} / \mathrm{ml}$ of IL6. PC3-DR cells were cultured in RPMI 1640 containing 10\% FCS, 1\% antibiotics, and glutaMax supplemented with $12.5 \mathrm{nM}$ docetaxel. All treatments with sorafenib were performed for $48 \mathrm{~h}$ in modified HITES medium (RPMI medium supplemented with $10 \mathrm{nM}$ hydrocortisone, $10 \mathrm{nM}$ estradiol, and $1 \times$ insulin-transferrin-selenium (Life Technologies, Vienna, Austria)).

\section{Chemicals and plasmids}

Sorafenib tosylate (BAY 43-9006) was provided by Bayer and dissolved in dimethylsulfoxide (DMSO) to a stock concentration of $10 \mathrm{mM}$. Bicalutamide (Casodex was kindly provided by Astrazeneca (Macclesfield, UK) and dissolved in DMSO to a stock concentration of $10 \mathrm{mM}$. Controls were treated with the corresponding volume of the vehicle. The MCL-1 expression vector was purchased from OriGene (Rockville, MD, USA).

\section{Proliferation assays}

LNCaP-IL6 +, LNCaP-Bic, PC3, and PC3-DR cells were seeded at a density of $6 \times 10^{3}$ per well, and $\mathrm{LNCaP}$ and 22Rv1 cells were seeded at a density of $1 \times 10^{4}$ per well in triplicates onto 96 well plates. Plates for $\mathrm{LNCaP}$ cells were previously coated with poly-D-lysine hydrobromide (30 $\mu \mathrm{g} / \mathrm{ml}$; Sigma-Aldrich). On the next day, the cells were treated with increasing concentrations of sorafenib $(0-2 \mu \mathrm{M})$ alone or in combination with docetaxel or bicalutamide for $48 \mathrm{~h}$ in modified HITES medium. The cells were incubated for the last $16 \mathrm{~h}$ of treatment with $37 \mathrm{kBq} /$ well ${ }^{3} \mathrm{H}$-thymidine and DNA was measured as described before (Puhr et al. 2010).

\section{Western blotting}

Western blot analysis was performed as described previously (Cavarretta et al. 2007). The following antibodies were used for western blots: anti-MCL-1 (1:500; Santa Cruz Biotechnology, Santa Cruz, CA, USA), anti-glyceraldehyde-3-phosphate dehydrogenase (GAPDH; 1:100 000; Chemicon International
Inc., Billerica, MA, USA), anti-phospho Akt (S473; 1:1000; Cell Signaling Technology, Danvers, MA, USA), anti-Akt (1:1000; Cell Signaling Technology), anti-phospho GSK-3 $\beta$ (S9; 1:500; Cell Signaling Technology), anti-GSK-3 $\beta$ (1:1000; Cell Signaling Technology), anti-AR (1:500; Santa Cruz Biotechnology), anti-cyclin-dependent kinase 2 (CDK2; 1:1000; Santa Cruz Biotechnology), and anti-cyclin D1 (1:1000; Neomarkers Inc., Fremont, CA, USA).

\section{Short interfering RNA transfection}

$\mathrm{LNCaP}$ and 22Rv1 cells were plated at low density in the presence of $10 \%$ FCS onto six well tissue culture plates previously coated with poly-D-lysine hydrobromide $(30 \mu \mathrm{g} / \mathrm{ml}$, for experiments with $\mathrm{LNCaP}$ cells; Sigma-Aldrich). One day later, the cells were transfected using Lipofectamine 2000 in serum- and antibiotics-free medium with $10 \mathrm{nM}$ ligand-binding domain (LBD) short interfering RNA (siRNA) according to the manufacturer's protocol (Invitrogen). The target sequence for AR LBD was published previously (Desiniotis et al. 2010). A nontargeting siRNA pool was used as a negative control and purchased from Dharmacon (Lafayette, CO, USA). Six hours after transfection, medium was changed to full growth conditions for overnight. On the next day, treatment with sorafenib $(2 \mu \mathrm{M})$ was performed for $48 \mathrm{~h}$ in serum-free HITES medium. Cells were harvested for western blot analysis and caspase 3/7 activity assay.

\section{Apoptosis assay}

Cells were seeded onto six wells and treated with sorafenib $(0-4 \mu \mathrm{M})$ alone or in combination as described above. After $48 \mathrm{~h}$, the cells were harvested and centrifuged. Apoptosis was measured by using the PE Annexin V Apoptosis Detection Kit I in combination with flow cytometry (Becton Dickinson, Schwechat, Austria) according to the manufacturer's protocols. Assays for caspase 3/7 activity were performed with the Caspase-Glo 3/7 assay kit (Promega) according to the manufacturer's protocols (Santer et al. 2011).

\section{PSA measurements}

Supernatants of LNCaP and LNCaP-Bic cells after the treatment with sorafenib or bicalutamide for $48 \mathrm{~h}$ were collected and PSA concentration was determined on an Advia Centaur XP Immunoassay System (Siemens, Vienna, Austria). The cells were trypsinized and counted with a Casy Counter (Schärfe System $\mathrm{GmbH}$, Reutlingen, Germany). Secreted PSA concentrations were normalized to cell number. 


\section{Statistical analysis}

Student's $t$-test was used to assess significant differences between the control and the indicated treated group and was encoded as follows: $* P<0.05$; $* * P<0.01 ; * * * P<0.001$.

\section{Results}

\section{Sorafenib inhibits proliferation of prostate cancer cells in a dose-dependent manner and targets cell cycle control proteins}

In the first attempt we analyzed the consequences of sorafenib treatment on prostate cancer cell proliferation and expression of cell cycle regulatory proteins. AR-positive ( $\mathrm{LNCaP}$ and 22Rv1) and -negative (PC3 and LNCaP-IL6+) cell lines were cultured in the presence of increasing doses of sorafenib for $48 \mathrm{~h}$. Proliferation was analyzed using ${ }^{3} \mathrm{H}$-thymidine incorporation assay and protein expression was determined by western blotting. An inhibitory effect of sorafenib on proliferation of androgen-sensitive as well as castration-resistant cell lines in a dose-dependent manner was observable (Fig. 1A). Interestingly, subphysiological concentrations of sorafenib $(0.5-2 \mu \mathrm{M}$; Wilhelm et al. 2004) were sufficient to reduce proliferation of LNCaP, PC3, and LNCaP-IL6+ cells significantly.
A

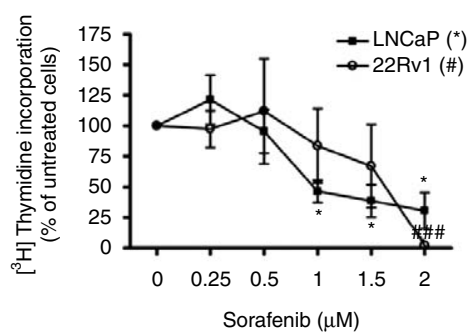

B
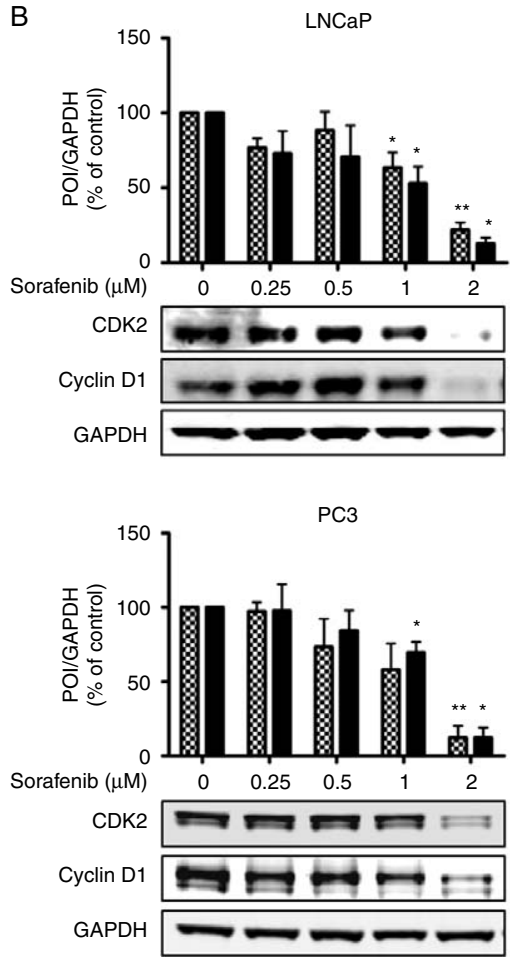
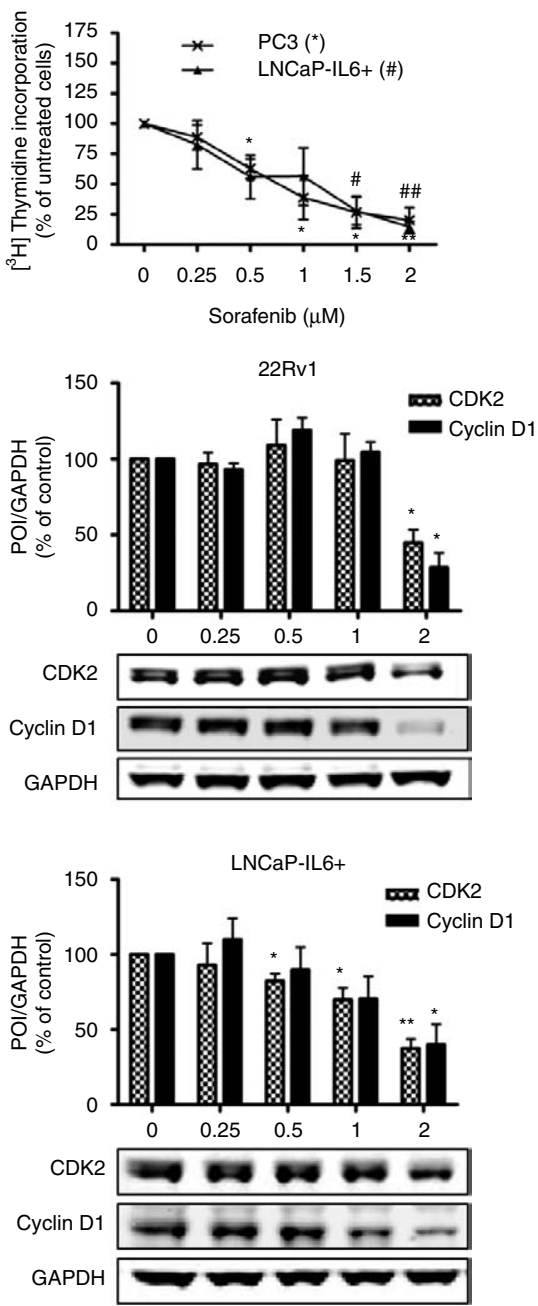

Figure 1 Dose-dependent inhibition of proliferation in prostate cancer cell lines by sorafenib. LNCaP, 22Rv1, PC3, and LNCaP-IL6+ cells were exposed to increasing concentrations of sorafenib in HITES medium for $48 \mathrm{~h}$. (A) Proliferation was assessed by ${ }^{3} \mathrm{H}$-thymidine incorporation. (B) Protein expression of CDK2 and cyclin D1 was detected by western blotting. Bands were scanned densitometrically and normalized to expression levels of GAPDH. Representative western blots from at least three independent experiments are shown. (A and $B$ ) Statistical significances are calculated against the DMSO-treated cells and values indicated are mean \pm S.E.M., $n \geq 3$. */\# $\mathrm{P}<0.05 ;{ }^{\star \star} / \# \# \mathrm{P}<0.01 ;{ }^{\star \star \star} / \# \# \# \mathrm{P}<0.001$. POI, protein of interest. 
Sensitivity of $22 \mathrm{Rv} 1$ to sorafenib was slightly decreased compared to other cell lines analyzed. Moreover, we observed a dose-dependent downregulation of cell cycle regulators CDK2 and cyclin D1 in all cell lines after $48 \mathrm{~h}$ of treatment (Fig. 1B), thus supporting the antiproliferative role of sorafenib.

\section{Sorafenib induces apoptosis in prostate cancer cells and downregulates MCL-1 and the Akt pathway}

To corroborate a possible apoptosis-inducing effect of sorafenib on prostate cancer cells, we performed flow cytometry using annexin V staining and caspase 3/7 activity assays (Fig. 2A and Supplementary Figure 1, see section on supplementary data given at the end of this article). Cells were exposed to increasing concentrations $(0-4 \mu \mathrm{M})$ of sorafenib for $48 \mathrm{~h}$. A physiological concentration of sorafenib $(2 \mu \mathrm{M})$ was sufficient to induce apoptosis in $\mathrm{LNCaP}$ and $22 \mathrm{Rv} 1$ cells significantly, while $4 \mu \mathrm{M}$ of sorafenib were required in PC3 and LNCaP-IL6 + cells. LNCaP cells treated with $4 \mu \mathrm{M}$ sorafenib underwent massive apoptosis resulting in an insufficient number of cells to perform assays. Taken together, these results demonstrate that AR-positive cell lines are more responsive to sorafenib-induced apoptosis than their counterparts which do not express the AR.

The antiapoptotic protein MCL-1 has been identified as one of the main targets of sorafenib in several cancers (Rahmani et al. 2005). Western blotting was performed to investigate whether MCL-1 is implicated in sorafenib-mediated apoptosis in prostate cancer cell lines. As shown in Fig. 2B, all cell lines expressed MCL-1 protein and sorafenib reduced its expression in a dose-dependent manner. In order to further study the role of MCL-1 in the induction of cell death by sorafenib, we have transfected PC3 cells with the MCL-1 expression vector and determined caspase 3/7 activity after treatment with sorafenib (Supplementary Figure 2, see section on supplementary data given at the end of this article). We confirmed overexpression of MCL-1, however the definitive answer to this question could not be given since $4 \mu \mathrm{M}$ of sorafenib treatment were sufficient to decrease MCL-1 expression.

We examined whether sorafenib can regulate phosphorylation of Akt and its direct downstream target GSK-3 $\beta$ in LNCaP and PC3 cells. Indeed, Akt phosphorylation at $\mathrm{S} 473$ was decreased by sorafenib in both cell lines as shown by western blot (Fig. 2C). Additionally, PC3 cells showed a decreased expression of nonphosphorylated Akt. Consequently, a reduced phosphorylation of GSK-3 $\beta$ was observable in LNCaP, while total GSK-3 $\beta$ expression was unaffected. In PC3 cells, GSK-3 $\beta$ phosphorylation at S9 was less prominent and nonphosphorylated GSK-3 $\beta$ was not influenced by sorafenib. Together, our data suggest that sorafenib is able to inactivate signaling through the Akt pathway.

\section{Inhibitory effects of sorafenib in therapy-resistant models of human prostate cancer}

Next, we evaluated the effects of sorafenib in the therapy-resistant cell models LNCaP-Bic and PC3-DR. Both cell lines that represent bicalutamide- or docetaxel-resistant prostate cancer were treated with increasing concentrations of sorafenib $(0-2 \mu \mathrm{M}$; Fig. 3). LNCaP-Bic cells showed the same sensitivity with regard to growth inhibition as measured by ${ }^{3} \mathrm{H}$-thymidine incorporation and downregulation of CDK2 and cyclin D1 by sorafenib as parental LNCaP cells. Compared to PC3 cells, a decreased sensitivity of the PC3-DR derivative to low concentrations of sorafenib $(0.5-1 \mu \mathrm{M})$ was observed, whereas doses higher than $1 \mu \mathrm{M}$ resulted in a similar inhibition of proliferation and decrease of CDK2 and cyclin D1. We hypothesized that docetaxel potentiates the effect of sorafenib in parental PC3 cells. Interestingly, there was no concentration-dependent effect of addition of docetaxel after sorafenib on proliferation and apoptosis of PC3 cells (Supplementary Figure 3, see section on supplementary data given at the end of this article).

On the other hand, in apoptosis assays both models showed different responses to sorafenib compared to parental cells (Fig. 4A and B). The concentration of $4 \mu \mathrm{M}$ sorafenib was in need to induce apoptosis in LNCaP-Bic cells, while $2 \mu \mathrm{M}$ was sufficient for parental LNCaP cells. Similarly, the PC3-DR subline showed a decreased sensitivity to sorafenib compared to parental PC3 cells. Again, expression levels of MCL-1 and phosphorylated and total Akt and GSK-3 $\beta$ were analyzed (Fig. 4C and Supplementary Figure 4, see section on supplementary data given at the end of this article). In both cell lines, phosphorylation of Akt was reduced by higher sorafenib concentrations. Interestingly, phosphorylation of GSK-3 $\beta$ was completely lost in LNCaP-Bic leading to the hypothesis for a role for GSK-3 $\beta$ in therapy resistance development. Altogether, these results show a decreased sensitivity of the therapyresistant cell models to sorafenib compared to parental cell lines. 
A

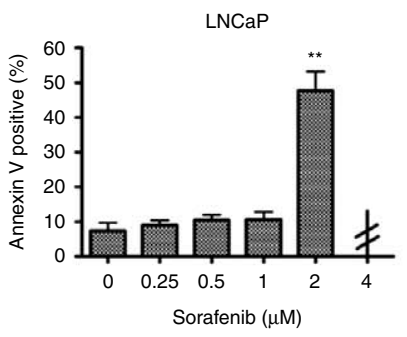

PC3

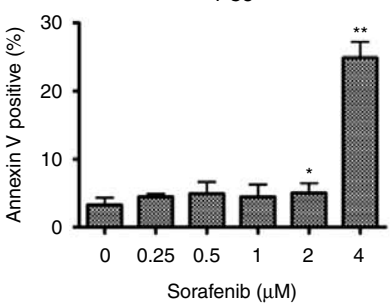

B
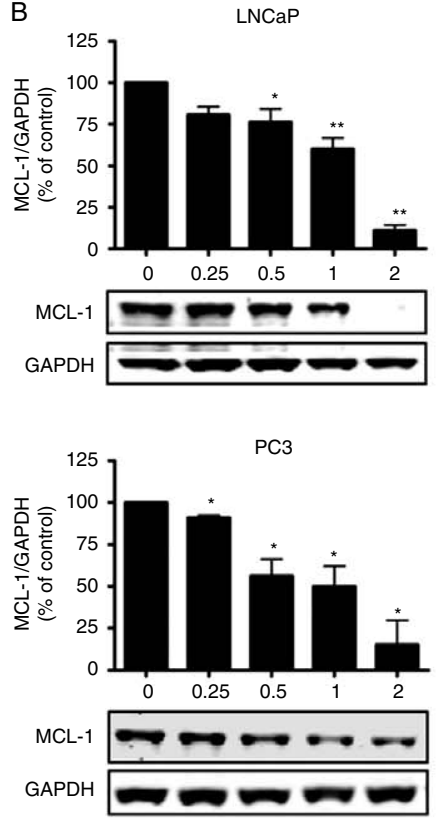

C

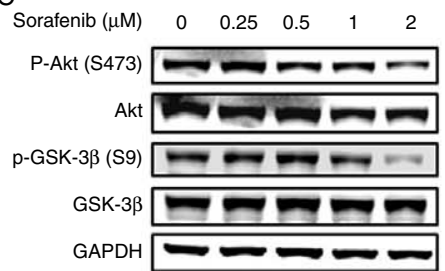

22Rv1

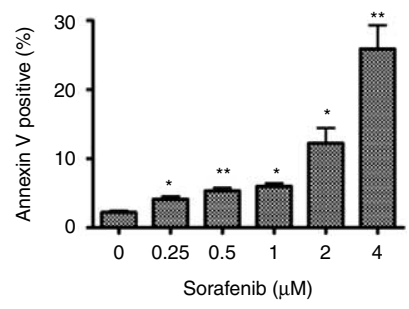

LNCaP-IL6+

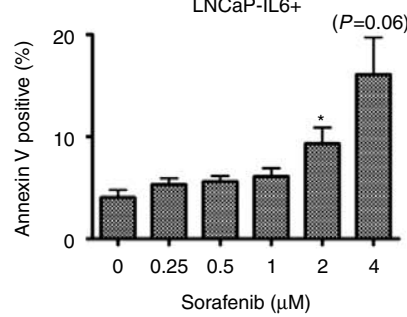

22Rv1

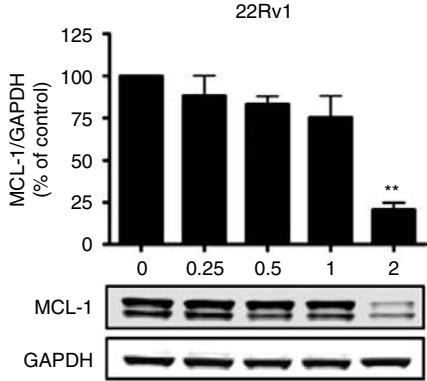

LNCaP-IL6+

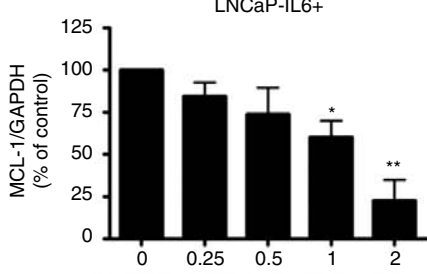

MCL-1

GAPDH

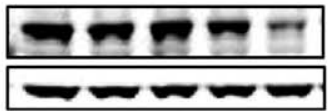

$\mathrm{PC} 3$

$\begin{array}{lllll}0 & 0.25 & 0.5 & 1 & 2\end{array}$

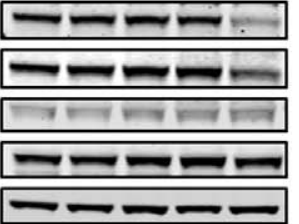

Figure 2 Differential sensitivities of prostate cancer cell lines to sorafenib-mediated apoptosis through downregulation of MCL-1 and Akt pathway. LNCaP, 22Rv1, PC3, and LNCaP-IL6 + cells were exposed to increasing concentrations of sorafenib in HITES medium for $48 \mathrm{~h}$. (A) Apoptosis was determined by PE/Annexin $\mathrm{V}$ staining and flow cytometry. LNCaP cells treated with $4 \mu \mathrm{M}$ sorafenib underwent massive apoptosis resulting in an insufficient number of cells to perform assays. (B) Expression of MCL-1 was determined by western blotting. Bands were scanned densitometrically and normalized to expression levels of GAPDH. (C) Expression levels and phosphorylation status of Akt and GSK-3 $\beta$ in LNCaP and PC3 cells were determined by western blotting. GAPDH served as loading control. (A and B) Statistical significances are calculated against the DMSO-treated cells and values indicated are mean \pm S.E.M., $n \geq 3$. ${ }^{*} \mathrm{P}<0.05 ;{ }^{* *} \mathrm{P}<0.01 ;{ }^{* \star *} \mathrm{P}<0.001$. Representative western blots from at least three independent experiments are shown. 
Sorafenib inhibits expression of AR and reduces PSA levels in androgen-sensitive cell lines

Modulation of AR signaling by the Her-2 tyrosine kinase has been reported (Craft et al. 1999). However, little is known about the regulation of AR signaling by tyrosine kinase inhibitors. $\mathrm{LNCaP}$ cells were more sensitive to sorafenib than LNCaP-Bic or LNCaP-abl cells (Fig. 4 and Supplementary Figure 5, see section on supplementary data given at the end of this article). Increased AR expression in LNCaP-abl cells was demonstrated in a previous publication of our laboratory (Culig et al. 1999). Thus, we hypothesized that AR is a target of sorafenib in prostate cancer cells. To clarify possible effects of sorafenib on AR, receptor expression levels were measured in LNCaP, 22Rv1, and LNCaP-Bic cells (Fig. 5A). In LNCaP and 22Rv1 cells, AR levels were decreased in the presence of $2 \mu \mathrm{M}$ sorafenib (Fig. 5A). In LNCaP-Bic cells which express higher levels of AR, AR protein level was downregulated only by $4 \mu \mathrm{M}$ of sorafenib. Moreover, concentration of secreted PSA was measured in all but the CRPC cell line 22Rv1 that lack detectable levels of secreted PSA under basal culture conditions (Tepper et al. 2002; Fig. 5B). In both LNCaP and LNCaP-Bic cells, secreted PSA levels were dramatically reduced in the presence of sorafenib. Intriguingly, sorafenib showed a higher ability to decrease PSA than bicalutamide at the same concentrations $(1-4 \mu \mathrm{M})$.

\section{Downregulation of AR by siRNA enhances sorafenib-induced increase of caspase 3/7 activity}

In regard to a possible clinical application of sorafenib for prostate cancer in combination with existing androgen-ablation therapies, we analyzed whether AR inhibition and sorafenib treatment have an additive effect. LNCaP and 22Rv1 cells were transfected with $10 \mathrm{nM}$ AR-LBD siRNA or control siRNA and treated with $2 \mu \mathrm{M}$ of sorafenib or vehicle (Fig. 6A). AR-LBD siRNA efficiently downregulated AR expression levels by $70-90 \%$ but did not affect expression levels of MCL-1. In the presence of $2 \mu \mathrm{M}$ of sorafenib, both AR and MCL-1 were downregulated as expected. AR expression was almost absent in the specific siRNAand sorafenib-treated samples. Apoptosis was induced in both cell lines after $48 \mathrm{~h}$ of sorafenib treatment as measured by caspase 3/7 assays (Fig. 6B). Moreover, a significant increase of apoptosis could be observed in 22Rv1 cells with decreased AR expression levels and treated with sorafenib compared to cells with reduced
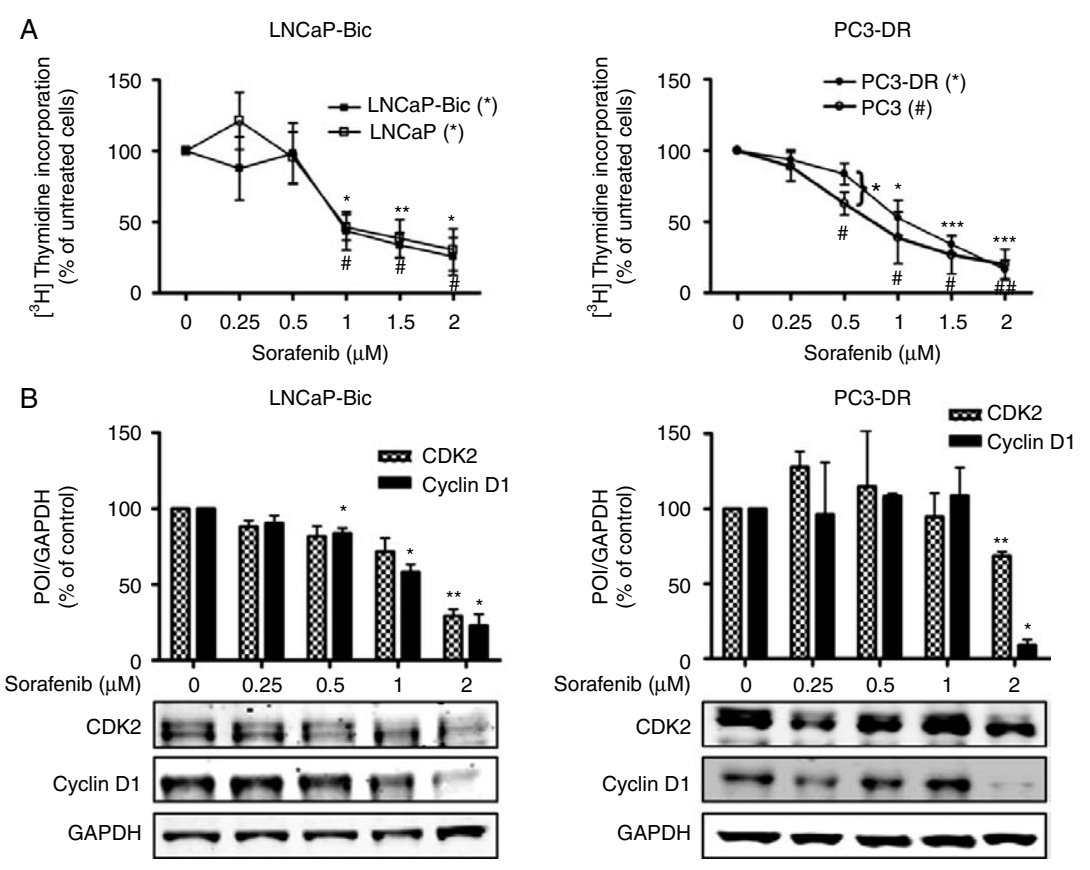

Figure 3 Antiproliferative effects of sorafenib in therapy-resistant models of human prostate cancer. LNCaP-Bic and PC3-DR were exposed to increasing concentrations of sorafenib in HITES medium for $48 \mathrm{~h}$. (A) Proliferation was assessed by ${ }^{3} \mathrm{H}$-thymidine incorporation. For comparison purposes results from Fig. 1A (LNCaP and PC3) are shown again. (B) Protein expression of CDK2 and cyclin D1 was detected by western blotting. Bands were scanned densitometrically and normalized to expression levels of GAPDH. Representative western blots from at least three independent experiments are shown. Statistical significances are calculated against the DMSO-treated cells and values indicated are mean \pm s.E.M., $n \geq 3 .{ }^{*} / \# \mathrm{P}<0.05 ;{ }^{\star \star} / \# \# \mathrm{P}<0.01 ;{ }^{\star \star \star} / \# \# \#$ $\mathrm{P}<0.001$. POI, protein of interest. 
A

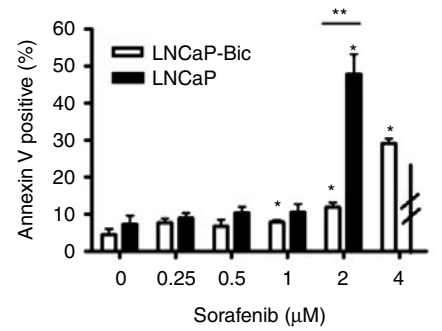

B

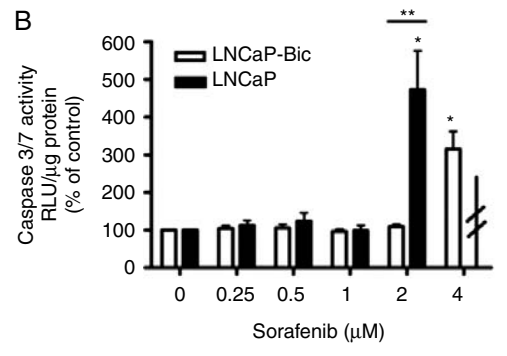

C

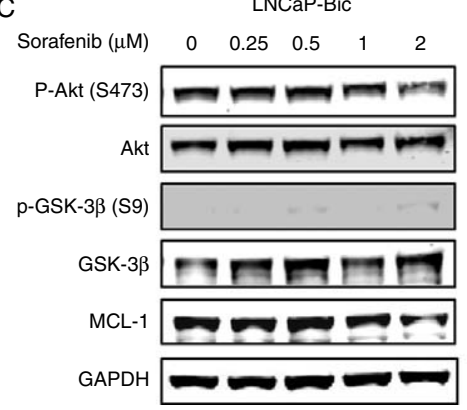

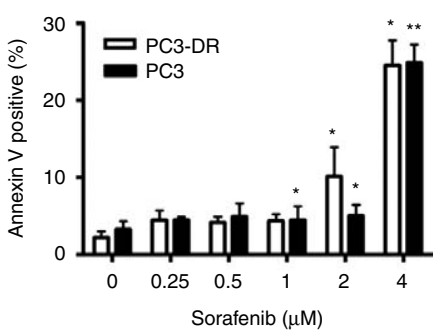

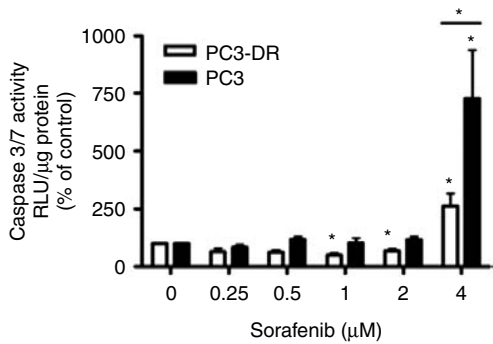

PC3-DR

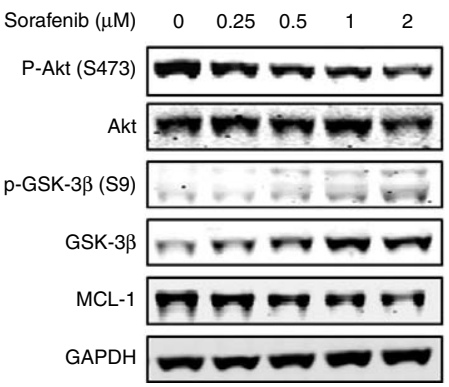

Figure 4 Therapy-resistant cells have decreased apoptotic sensitivity to sorafenib. LNCaP-Bic and PC3-DR were exposed to increasing concentrations of sorafenib in HITES medium for $48 \mathrm{~h}$. (A) Apoptosis was determined by PE/Annexin V staining and flow cytometry. For comparison purposes results from Fig. 2A (LNCaP and PC3) are shown again. (B) Activity of the executioner caspases 3 and 7 after addition of the specific substrate. (C) Expression levels and phosphorylation status of MCL-1, Akt, and GSK-3 $\beta$ were determined by western blotting. Representative western blots from at least three independent experiments are shown. ( $A$ and $B$ ) Statistical significances are calculated against the DMSO-treated cells or parental cells and values indicated are mean \pm S.E.M., $n \geq 3$. * $\mathrm{P}<0.05$; ${ }^{*} \mathrm{P}<0.01$; ${ }^{\star \star \star} \mathrm{P}<0.001$. RLU, relative light units.

AR expression only. In contrast to the experiments in which AR was downregulated by siRNA, cotreatment of LNCaP cells with sorafenib and bicalutamide did not cause additional inhibition of proliferation or stimulation of apoptosis (Supplementary Figure 3, see section on supplementary data given at the end of this article).

Altogether, these data demonstrate that inhibition of AR expression and sorafenib treatment have additive effects in apoptosis induction.

\section{Discussion}

In this study, we evaluated the therapeutic potential of sorafenib on several preclinical models of advanced prostate cancer including antiandrogen- and chemotherapy-resistant sublines. Our results demonstrated that physiological concentrations of sorafenib induce a dose-dependent inhibition of proliferation by downregulating key G1/S transition proteins CDK2 and cyclin D1 in all cell lines. Furthermore, sorafenib treatment enhanced apoptosis by targeting the Akt/GSK-3 $\beta$ prosurvival pathway and the antiapoptotic MCL-1. The antitumor activity of sorafenib by similar underlying molecular mechanisms in parental as well as in therapy-resistant cell lines indicates that sorafenib could be considered as an adjuvant treatment option in combination with current androgen ablation therapies, but could also have beneficial effects in the progressed stages of therapy-resistant prostate cancer.

\section{In vitro potential of sorafenib in therapy-resistant prostate cancer is determined by inhibition of AR expression}

Interestingly, AR-positive cell lines LNCaP and 22Rv1 were more responsive to sorafenib-induced apoptosis 


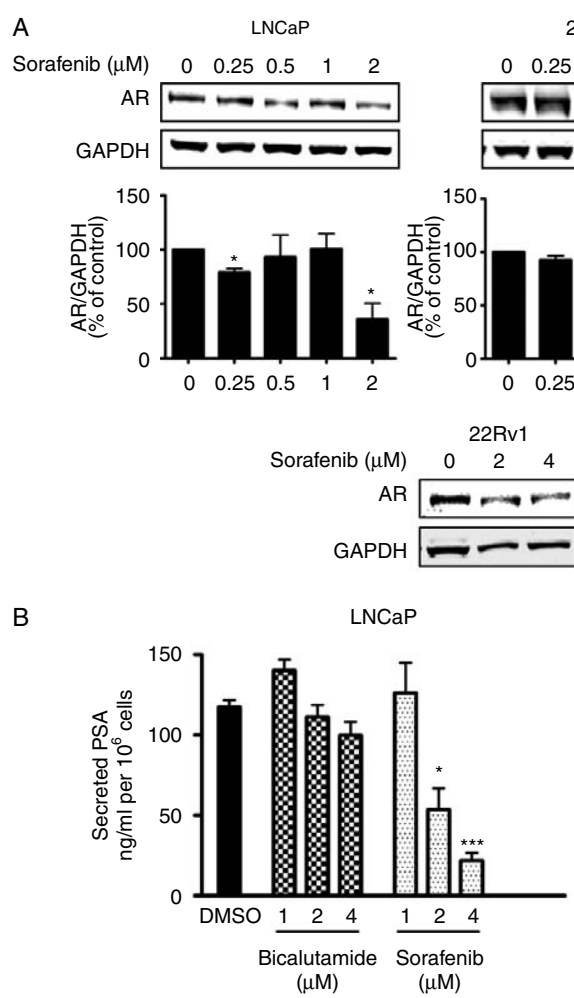

22Rv1

LNCaP-Bic
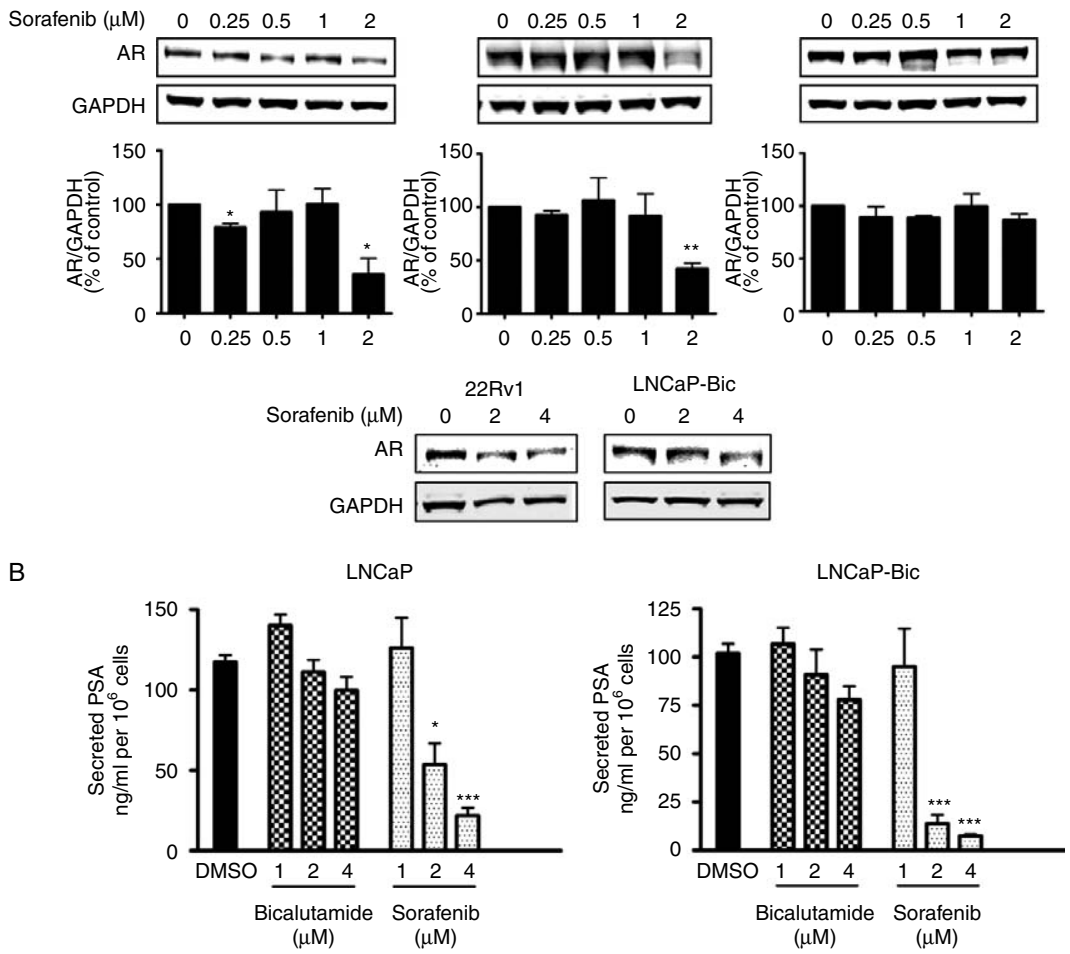

Figure 5 Sorafenib suppresses AR expression and decreases PSA secretion. (A) LNCaP, 22Rv1, and LNCaP-Bic were exposed to increasing concentration of sorafenib in HITES medium for $48 \mathrm{~h}$. (A) Protein expression of AR was detected by western blotting. Bands were scanned densitometrically and normalized to expression levels of GAPDH. Representative western blots from at least three independent experiments are shown. (B) LNCaP and LNCaP-Bic cells were treated with sorafenib or bicalutamide in HITES medium for $48 \mathrm{~h}$. Secreted PSA in the supernatants was measured and normalized to the respective cell number. (A and B) Statistical significances are calculated against the DMSO-treated cells and values indicated are mean \pm S.E.M., $n \geq 3$. ${ }^{*} \mathrm{P}<0.05$; ${ }^{* *} \mathrm{P}<0.01 ;{ }^{* \star *} \mathrm{P}<0.001$

than LNCaP-IL6 + or PC3 cells. Furthermore, 22Rv1 cells showed a diminished increase of apoptotic cells in comparison to $\mathrm{LNCaP}$ after treatment with $2 \mu \mathrm{M}$ of sorafenib. An explanation for this could be the fact that CRPC 22Rv1 cells display a decreased sensitivity to androgen in comparison to $\mathrm{LNCaP}$ due to an insertional mutation in the AR locus (Tepper et al. 2002). 22Rv1 cells express low levels of PSA mRNA and do not express detectable levels of PSA protein in androgen-depleted medium or after androgenic stimulation (Tepper et al. 2002). The AR pathway may be less important for the survival of 22Rv1 cells compared to LNCaP cells, thus explaining the difference in sensitivity to sorafenib with regard to apoptosis. The different responsiveness of androgensensitive and -insensitive cells could be explained by our findings obtained in experiments in which we investigated regulation of the AR signaling pathway by sorafenib. In this study, we report for the first time that sorafenib suppressed AR protein expression and decreased PSA levels. It is interesting to note that the dual epidermal growth factor receptor/Her-2 inhibitor
PKI-166 reduced AR expression and transcriptional activity (Mellinghoff et al. 2004). It is established that cancer progression toward castration resistance occurs in the presence of a functional androgen signaling pathway (Feldman \& Feldman 2001). AR overexpression may occur due to $A R$ gene amplification or increased stabilization of its mRNA or protein (Visakorpi et al. 1995). The state-of-the-art antiandrogen therapy is based on administration of AR antagonists such as hydroxyflutamide or bicalutamide. The use of these agents may be compromised because of emergence of receptor mutations during therapy or increased expression of cofactors which potentiate agonistic effects of hydroxyflutamide, such as CREBbinding protein (CBP) or gelsolin (Culig et al. 2005). For this reason, a novel AR antagonist, such as MDV3100, which acts by a different mechanism in comparison to bicalutamide by blocking AR nuclear translocation, impairing DNA binding to androgen response elements and recruitment of coactivators, is currently being tested in clinical trials (Tran et al. 2009). In contrast to MDV3100, sorafenib diminishes 
A

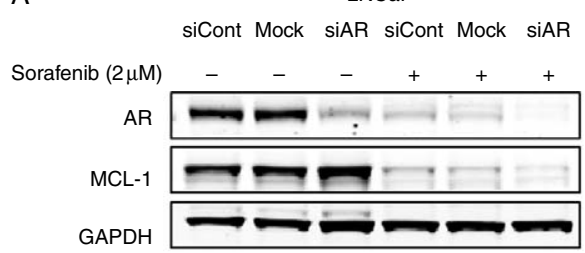

B

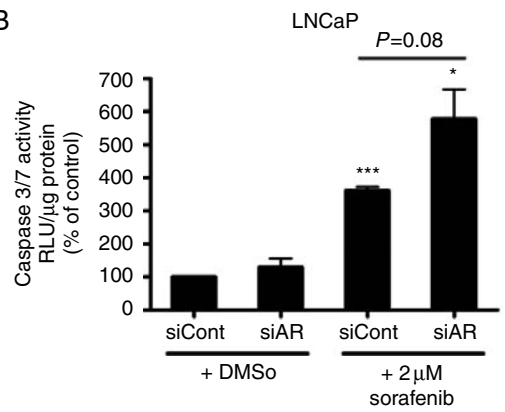

22Rv1

siCont Mock siAR siCont Mock siAR

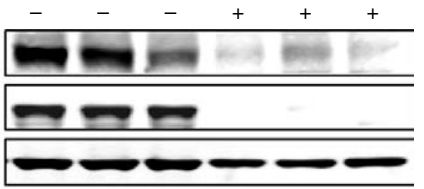

22Rv1

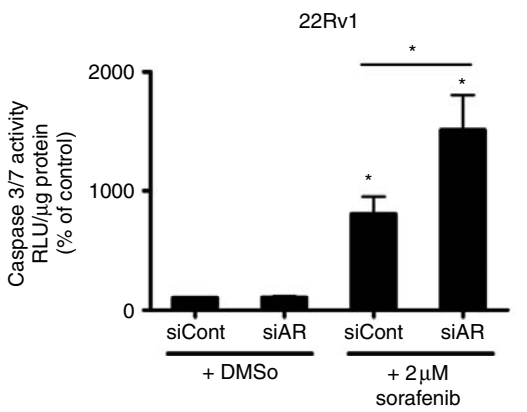

Figure 6 Downregulation of AR by siRNA enhances apoptotic sensitivity of androgen-sensitive cells to sorafenib. LNCaP and 22Rv1 cells were transfected with $10 \mathrm{nM}$ AR LBD siRNA and exposed on the next day to $2 \mu \mathrm{M}$ sorafenib or DMSO in HITES medium for $48 \mathrm{~h}$. (A) Protein expression of AR was detected by western blotting. GAPDH served as a loading control. Representative western blots from at least three independent experiments are shown. (B) Activity of the executioner caspases 3 and 7 after addition of the specific substrate. Values indicated are mean \pm S.E.M., $n \geq 3$. ${ }^{*} \mathrm{P}<0.05 ;{ }^{* \star} \mathrm{P}<0.01 ;{ }^{* * *} \mathrm{P}<0.001$. RLU, relative light units.

AR expression. Inhibitory effects of sorafenib on expression of other steroid receptors have not been reported so far. Our data may initiate studies in other endocrine-related cancers in which possible effects of sorafenib on steroid receptors could be investigated. Although the possibility that the observed effect of sorafenib is a consequence of cell death that cannot be completely ruled out, it has to be mentioned that higher concentrations of sorafenib are required for induction of apoptosis in two LNCaP sublines which express increased AR levels (Culig et al. 1999), thus supporting the conception that AR inhibition by sorafenib precedes cell death.

Our results also justify considerations about the development of a more efficient combination therapy in prostate cancer with sorafenib as one of the compounds used. Additive effects of AR siRNA and sorafenib support the combination therapy approach and may lead to a reduction of doses of sorafenib which cause a therapeutical benefit. Interestingly, in contrast to the experiments performed with AR siRNA there was no additional effect of cotreatment of LNCaP cells with sorafenib and bicalutamide which interferes with AR function. Sorafenib has already shown enhanced antitumor activity combined with other agents such as docetaxel, vitamin $\mathrm{K}$, TRAIL, or radiation treatment in multiple cancers (Huang \& Sinicrope 2010, Ulivi et al. 2010, Wei et al. 2010, Yadav et al. 2011). Importantly, the combinatorial effects of sorafenib and other drugs may strongly depend on the drug sequence employed (Ulivi et al. 2010). For instance, drug metabolism may be regulated in a different manner after various drug administration sequences.

\section{Efficiency of sorafenib in endocrine- and chemotherapy-resistant models}

In order to test the hypothesis that there is a rationale for administration of sorafenib in prostate cancer that is resistant to endocrine or chemotherapy, we treated the sublines LNCaP-Bic and PC3-DR, resistant to bicalutamide and docetaxel respectively. Importantly, there was no major difference in proliferative responsiveness to sorafenib between parental and antiandrogenresistant cells. This was not surprising since cell cycle regulatory proteins were similarly inhibited in both parental and therapy-resistant sublines. AR expression was also reduced by sorafenib in LNCaPBic, however higher concentrations of sorafenib were required to achieve this effect. Likewise, induction of apoptosis in the androgen-independent LNCaP-Bic subline was only observed after treatment with higher drug doses. AR expression increased in LNCaP-Bic cells in comparison to those reported in a previous study (Hobisch et al. 2006); however, higher passages of the resistant subline were used in the present work.

According to the data available in the literature, the development of docetaxel resistance in prostate cancer is a complex cell line-specific process (Madan et al. 2011). Examples of the upregulated proteins in 
docetaxel resistance include but are not limited to Pim-1 kinase, chemokine CCL2, and class III $\beta$ tubulin (Zemskova et al. 2008, Ploussard et al. 2010, Qian et al. 2010). Identification of additional mechanisms being responsible for resistance of the sublines derived in our laboratory is at present under investigation. However, although efficacy of growth inhibition and apoptosis induction of PC3-DR is somewhat reduced compared to parental cells, it is important to note that PC3-DR could still be inhibited by sorafenib but no longer by docetaxel. This finding may have clinical implications especially when keeping in mind that the duration of docetaxel response in prostate cancer patients is limited to several months.

\section{Antiapoptotic pathways in prostate cancer cells are inhibited by sorafenib}

In concordance to findings observed in other tumors, inhibition of Akt phosphorylation by sorafenib was also seen in our experiments in LNCaP and PC 3 cells (Chapuy et al. 2011). The Akt signaling pathway is frequently activated in advanced prostate cancer due to deletion or mutation of the PTEN tumor suppressor gene (Sircar et al. 2009). In cell culture models, Akt is constitutively active in LNCaP and PC3 cells due to PTEN mutation (LNCaP) or deletion (PC3; Vlietstra et al. 1998). In line with those data, Kreisberg et al. (2004) showed that phosphorylation of Akt S473 is a predictor of poor clinical outcome in prostate cancer. Moreover, it is known that the Akt downstream target GSK-3 $\beta$ mediates degradation of MCL-1 by the proteasome. Interestingly, differences in phosphorylation of GSK-3 $\beta$ in prostate cancer after sorafenib treatment were observed in a cell type-dependent manner. GSK-3 $\beta$ is phosphorylated and inactivated by phosphorylated Akt. Consequently, phosphorylation of GSK-3 $\beta$ may lead to upregulation of MCL-1 in multiple tumor cell lines and primary cancer samples (Maurer et al. 2006). As an implication of sorafenib treatment, downregulation of MCL-1 could be achieved by a decrease of total or inactivated, i.e. phosphorylated GSK-3 $\beta$. It is known that MCL-1 is expressed at high levels in prostate cancer and is important for mediating a survival function of the proinflammatory cytokine IL6 (Krajewska et al. 1996, Cavarretta et al. 2007). Taken together, our results suggest the sorafenib-mediated modulation of the Akt/ GSK-3 $\beta /$ MCL-1 pathway in prostate cancer is clinically relevant. Although the results of our overexpression experiments cannot definitively answer the question whether the presence of MCL-1 is required for the antiapoptotic effect of sorafenib in prostate cancer cells, there is an evidence in the scientific literature supporting this view. First, in K562 chronic myelogenous leukemia cells overexpression of MCL-1 inhibited sorafenib-induced apoptosis (Yu et al. 2005). In addition, in a recent study performed in androgen-insensitive prostate cancer cell lines sorafenib sensitized tumor cells to (-)gossypol through MCL-1 inhibition (Lian et al. 2012).

\section{The perspective for further development of sorafenib-based prostate cancer treatments}

Three preclinical studies have addressed the drug response of sorafenib on prostate cancer cells in vitro (Dahut et al. 2008, Huang et al. 2010, Ullen et al. 2010). In contrast to our work, those reports were focused on antiangiogenic and cytotoxic effects of sorafenib. Moreover, they were performed in a single prostate cancer cell line using concentrations of the drug which were higher than the physiological concentrations of $2-5 \mu \mathrm{M}$ measured in sera of patients after administration of $400 \mathrm{mg}$ twice daily (Dahut et al. 2008). In one of those previous studies, decreased phosphorylation of MAP kinases by sorafenib in PC3 and DU145 cells was observed (Ullen et al. 2010) confirming the results in colon, pancreas, and breast cancer cell lines (Wilhelm et al. 2004). However, other signaling pathways were not investigated after sorafenib treatment in prostate cancer in previous reports.

Our results may have implications for development of clinical prostate cancer therapies. Tannock et al. (2004) documented that docetaxel-based chemotherapy in combination with prednisone improved median overall survival of patients with CRPC by 2.4 months. However, because of limited benefits and significant toxicity of docetaxel therapy, the search for a more efficient treatment for CRPC is continued. On the basis of a recent publication by de Bono et al. (2011) that administration of the inhibitor of androgen synthesis abiraterone in combination with prednisone in patients pretreated with docetaxel prolonged survival to $450 \mathrm{vs}$ 332 days, it could be concluded that targeting the androgen signaling pathway in docetaxel-resistant prostate cancer in vivo is nevertheless a worthy therapeutic goal. The question whether a combinatorial treatment on the basis of androgenic and multiple kinase inhibition by sorafenib has a benefit in patients with therapy-resistant prostate cancer needs to be addressed in the future.

Clinical studies have reported benefits following treatment with tyrosine kinase inhibitors erlotinib and sunitinib in prostate cancer patients (Gravis et al. 2008, Sonpavde et al. 2008). In other clinical trials, the 
investigators reported on a small number of patients in which stabilization of the disease by sorafenib was achieved (Chi et al. 2008, Dahut et al. 2008, Steinbild et al. 2007, Aragon-Ching et al. 2009). On the other hand, difficulties in correlating clinical response and PSA measurements were observed. In the context of the final analysis of a phase II trial, Aragon-Ching et al. (2009) suggested that a selected population of patients may benefit from sorafenib treatment. The absence of adequate biomarkers for monitoring the therapeutic success may be the reason why it is difficult to match preclinical findings with clinical effects. It should be mentioned that PSA measurements in vitro could not be simply extrapolated in vivo since the patients' data also reflect the disruption of the basement membrane. In a recently reported phase II clinical trial with sorafenib and bicalutamide in patients with CRPC 47\% of patients presented with either PSA decrease or stable disease (Beardsley et al. 2012). Those clinical findings could be partly explained by our results showing differences in responsiveness of prostate cancer parental cells and sublines representing advanced disease stages to sorafenib.

In summary, we demonstrate that the multitargeting effects of sorafenib induce growth inhibition and apoptosis in a variety of prostate cancer cell lines. Most importantly, we found that sorafenib affects AR expression and signaling, which is a previously unknown mechanism of sorafenib. Our data also suggest that maximal effect of sorafenib may be expected in androgen-sensitive prostate cancer prior to the development of resistance to castration and chemotherapy. However, there may be also a rationale for the use of sorafenib in docetaxel-resistant carcinoma of the prostate. The evidence for differential response of prostate cancer cell lines may explain why sorafenib is beneficial in a selected population of patients in clinical trials.

\section{Supplementary data}

This is linked to the online version of the paper at http://dx. doi.org/10.1530/ERC-11-0298.

\section{Declaration of interest}

The authors declare that there is no conflict of interest that could be perceived as prejudicing the impartiality of the research reported.

\section{Funding}

This work was supported by the Austrian Science Fund (FWF, grant number L544 to Z Culig), Austrian National
Bank (OENB, grant number 13952 to Z Culig), and Bayer Austria. Research support by Bayer Austria (to Z Culig) was received.

\section{Author contribution statement}

S J Oh performed research, analyzed data, wrote the first version of the paper; H H H Erb performed research, analyzed data; A Hobisch designed research; F R Santer performed and supervised research, analyzed data, prepared the final version of the paper; $\mathrm{Z}$ Culig designed and supervised research, and prepared the final version of the paper. All authors have participated in writing and approved the final version of the paper.

\section{Acknowledgements}

We thank Ms Tanja Fuchs and Birgit Stenzel for PSA measurements. We are grateful to all members of the Culig laboratory for their discussions during preparation of the manuscript, Dr Walther Parson for cell authentication, Dr Dennis Healy and Mr Gerhard Briesch for providing sorafenib.

\section{References}

Aragon-Ching JB, Jain L, Gulley JL, Arlen PM, Wright JJ, Steinberg SM, Draper D, Venitz J, Jones E, Chen CC et al. 2009 Final analysis of a phase II trial using sorafenib for metastatic castration-resistant prostate cancer. British Journal of Urology International 103 1636-1640. (doi:10.1111/j.1464-410X.2008.08327.x)

Beardsley EK, Hotte SJ, North S, Ellard SL, Winquist E, Kollmannsberger C, Mukherjee SD \& Chi KN 2012

A phase II study of sorafenib in combination with bicalutamide in patients with chemotherapy-naive castration resistant prostate cancer. Investigational New Drugs [in press].

de Bono JS, Logothetis CJ, Molina A, Fizazi K, North S, Chu L, Chi KN, Jones RJ, Goodman OB Jr, Saad F et al. 2011 Abiraterone and increased survival in metastatic prostate cancer. New England Journal of Medicine 364 1995-2005. (doi:10.1056/NEJMoa1014618)

Cavarretta IT, Neuwirt H, Untergasser G, Moser PL, Zaki MH, Steiner H, Rumpold H, Fuchs D, Hobisch A, Nemeth JA et al. 2007 The antiapoptotic effect of IL-6 autocrine loop in a cellular model of advanced prostate cancer is mediated by Mcl-1. Oncogene 26 2822-2832. (doi:10.1038/sj.onc. 1210097)

Chapuy B, Schuelper N, Panse M, Dohm A, Hand E, Schroers R, Truemper L \& Wulff GG 2011 Multikinase inhibitor sorafenib exerts cytocidal efficacy against non-Hodgkin lymphomas associated with inhibition of MAPK14 and AKT phosphorylation. British Journal of Haematology 152 401-412. (doi:10.1111/j.1365-2141. 2010.08526.x) 
Chi KN, Ellard SL, Hotte SJ, Czaykowski P, Moore M, Ruether JD, Schell AJ, Taylor S, Hansen C, Gauthier I et al. 2008 A phase II study of sorafenib in patients with chemo-naive castration-resistant prostate cancer. Annals of Oncology 19 746-751. (doi:10.1093/annonc/ mdm554)

Craft N, Shostak Y, Carey M \& Sawyers CL 1999 A mechanism for hormone-independent prostate cancer through modulation of androgen receptor signaling by the HER-2/neu tyrosine kinase. Nature Medicine 5 280-285. (doi:10.1038/6495)

Craig RW 2002 MCL1 provides a window on the role of the BCL2 family in cell proliferation, differentiation and tumorigenesis. Leukemia 16 444-454. (doi:10.1038/sj. leu.2402416)

Culig Z, Hoffmann J, Erdel M, Eder IE, Hobisch A, Hittmair A, Bartsch G, Utermann G, Schneider MR, Parczyk K et al. 1999 Switch from antagonist to agonist of the androgen receptor blocker bicalutamide is associated with prostate tumour progression in a new model system. British Journal of Cancer 81 242-251. (doi:10.1038/sj.bjc. 6690684)

Culig Z, Steiner H, Bartsch G \& Hobisch A 2005 Mechanisms of endocrine therapy-responsive and -unresponsive prostate tumours. Endocrine-Related Cancer 12 229-244. (doi:10.1677/erc.1.00775a)

Dahut WL, Scripture C, Posadas E, Jain L, Gulley JL, Arlen PM, Wright JJ, Yu Y, Cao L, Steinberg SM et al. 2008 A phase II clinical trial of sorafenib in androgenindependent prostate cancer. Clinical Cancer Research 14 209-214. (doi:10.1158/1078-0432.CCR-07-1355)

Desiniotis A, Schafer G, Klocker H \& Eder IE 2010 Enhanced antiproliferative and proapoptotic effects on prostate cancer cells by simultaneously inhibiting androgen receptor and cAMP-dependent protein kinase A. International Journal of Cancer 126 775-789. (doi:10.1002/ijc.24806)

Ding Q, He X, Hsu JM, Xia W, Chen CT, Li LY, Lee DF, Liu JC, Zhong Q, Wang X et al. 2007 Degradation of Mcl-1 by beta-TrCP mediates glycogen synthase kinase 3 -induced tumor suppression and chemosensitization. Molecular and Cellular Biology 27 4006-4017. (doi:10.1128/MCB.00620-06)

Feldman BJ \& Feldman D 2001 The development of androgen-independent prostate cancer. Nature Reviews. Cancer 1 34-45. (doi:10.1038/35094009)

Gravis G, Bladou F, Salem N, Goncalves A, Esterni B, Walz J, Bagattini S, Marcy M, Brunelle S \& Viens $P$ 2008 Results from a monocentric phase II trial of erlotinib in patients with metastatic prostate cancer. Annals of Oncology 19 1624-1628. (doi:10.1093/ annonc/mdn174)

Grossmann ME, Huang H \& Tindall DJ 2001 Androgen receptor signaling in androgen-refractory prostate cancer. Journal of the National Cancer Institute 93 1687-1697. (doi:10.1093/jnci/93.22.1687)
Ha S, Ruoff R, Kahoud N, Franke TF \& Logan SK 2011 Androgen receptor levels are upregulated by Akt in prostate cancer. Endocrine-Related Cancer 18 245-255. (doi:10.1530/ERC-10-0204)

Hobisch A, Ramoner R, Fuchs D, Godoy-Tundidor S, Bartsch G, Klocker H \& Culig Z 2001 Prostate cancer cells (LNCaP) generated after long-term interleukin 6 (IL-6) treatment express IL-6 and acquire an IL-6 partially resistant phenotype. Clinical Cancer Research 7 2941-2948.

Hobisch A, Fritzer A, Comuzzi B, Fiechtl M, Malinowska K, Steiner H, Bartsch G \& Culig Z 2006 The androgen receptor pathway is by-passed in prostate cancer cells generated after prolonged treatment with bicalutamide. Prostate 66 413-420. (doi:10.1002/pros.20365)

Huang S \& Sinicrope FA 2010 Sorafenib inhibits STAT3 activation to enhance TRAIL-mediated apoptosis in human pancreatic cancer cells. Molecular Cancer Therapeutics 9 742-750. (doi:10.1158/1535-7163.MCT09-1004)

Huang R, Chen XQ, Huang Y, Chen N \& Zeng H 2010 The multikinase inhibitor sorafenib induces caspasedependent apoptosis in PC-3 prostate cancer cells. Asian Journal of Andrology 12 527-534. (doi:10.1038/ aja.2010.21)

Jemal A, Siegel R, Xu J \& Ward E 2010 Cancer statistics, 2010. CA: A Cancer Journal for Clinicians 60 277-300. (doi:10.3322/caac.20073)

Kane RC, Farrell AT, Saber H, Tang S, Williams G, Jee JM, Liang C, Booth B, Chidambaram N, Morse D et al. 2006 Sorafenib for the treatment of advanced renal cell carcinoma. Clinical Cancer Research 12 7271-7278. (doi:10.1158/1078-0432.CCR-06-1249)

Kozopas KM, Yang T, Buchan HL, Zhou P \& Craig RW 1993 MCL1, a gene expressed in programmed myeloid cell differentiation, has sequence similarity to BCL2. PNAS 90 3516-3520. (doi:10.1073/pnas.90.8.3516)

Krajewska M, Krajewski S, Epstein JI, Shabaik A, Sauvageot J, Song K, Kitada S \& Reed JC 1996 Immunohistochemical analysis of bcl-2, bax, bcl-X, and mcl-1 expression in prostate cancers. American Journal of Pathology 148 1567-1576.

Kreisberg JI, Malik SN, Prihoda TJ, Bedolla RG, Troyer DA, Kreisberg S \& Ghosh PM 2004 Phosphorylation of Akt (Ser473) is an excellent predictor of poor clinical outcome in prostate cancer. Cancer Research 64 5232-5236. (doi:10.1158/0008-5472.CAN-04-0272)

Lang L 2008 FDA approves sorafenib for patients with inoperable liver cancer. Gastroenterology 134379.

Lian J, Ni Z, Dai X, Su C, Smith AR, Xu L \& He F 2012 Sorafenib sensitizes ( - )-gossypol-induced growth suppression in androgen-independent prostate cancer cells via Mcl-1 inhibition and Bak activation. Molecular Cancer Therapeutics 11 416-426. (doi:10.1158/15357163.MCT-11-0559) 
Madan RA, Pal SK, Sartor O \& Dahut WL 2011 Overcoming chemotherapy resistance in prostate cancer. Clinical Cancer Research 17 3892-3902. (doi:10.1158/10780432.CCR-10-2654)

Maurer U, Charvet C, Wagman AS, Dejardin E \& Green DR 2006 Glycogen synthase kinase-3 regulates mitochondrial outer membrane permeabilization and apoptosis by destabilization of MCL-1. Molecular Cell 21 749-760. (doi:10.1016/j.molcel.2006.02.009)

Mellinghoff IK, Vivanco I, Kwon A, Tran C, Wongwipat J \& Sawyers CL 2004 HER2/neu kinase-dependent modulation of androgen receptor function through effects on DNA binding and stability. Cancer Cell 6 517-527. (doi:10.1016/j.ccr.2004.09.031)

Nesterov A, Lu X, Johnson M, Miller GJ, Ivashchenko Y \& Kraft AS 2001 Elevated AKT activity protects the prostate cancer cell line LNCaP from TRAIL-induced apoptosis. Journal of Biological Chemistry 276 10767-10774. (doi:10.1074/jbc.M005196200)

Patterson SG, Wei S, Chen X, Sallman DA, Gilvary DL, Zhong B, Pow-Sang J, Yeatman T \& Djeu JY 2006 Novel role of Stat 1 in the development of docetaxel resistance in prostate tumor cells. Oncogene 25 6113-6122. (doi:10.1038/sj.onc.1209632)

Ploussard G, Terry S, Maille P, Allory Y, Sirab N, Kheuang L, Soyeux P, Nicolaiew N, Coppolani E, Paule B et al. 2010 Class III beta-tubulin expression predicts prostate tumor aggressiveness and patient response to docetaxel-based chemotherapy. Cancer Research 70 9253-9264. (doi:10.1158/0008-5472.CAN-10-1447)

Puhr M, Santer FR, Neuwirt H, Marcias G, Hobisch A \& Culig Z 2010 SOCS-3 antagonises the proliferative and migratory effects of fibroblast growth factor-2 in prostate cancer by inhibition of p44/p42 MAPK signalling. Endocrine-Related Cancer 17 525-538. (doi:10.1677/ERC-10-0007)

Qian DZ, Rademacher BL, Pittsenbarger J, Huang CY, Myrthue A, Higano CS, Garzotto M, Nelson PS \& Beer TM 2010 CCL2 is induced by chemotherapy and protects prostate cancer cells from docetaxel-induced cytotoxicity. Prostate 70 433-442.

Rahmani M, Davis EM, Bauer C, Dent P \& Grant S 2005 Apoptosis induced by the kinase inhibitor BAY 43-9006 in human leukemia cells involves down-regulation of Mcl-1 through inhibition of translation. Journal of Biological Chemistry 280 35217-35227. (doi:10.1074/jbc.M506551200)

Santer FR, Höschele PP, Oh SJ, Erb HH, Bouchal J, Cavarretta IT, Parson W, Meyers DJ, Cole PA \& Culig Z 2011 Inhibition of the acetyltransferases p300 and CBP reveals a targetable function for p300 in the survival and invasion pathways of prostate cancer cell lines. Molecular Cancer Therapeutics 10 1644-1645. (doi:10.1158/15357163.MCT-11-0182)

Sircar K, Yoshimoto M, Monzon FA, Koumakpayi IH, Katz RL, Khanna A, Alvarez K, Chen G, Darnel AD, Aprikian AG et al. 2009 PTEN genomic deletion is associated with p-Akt and AR signalling in poorer outcome, hormone refractory prostate cancer. Journal of Pathology 218 505-513. (doi:10.1002/path.2559)

Sonpavde G, Hutson TE, Berry WR, Boehm KA \& Asmar L 2008 Phase II trial of sunitinib for the therapy of progressive metastatic castration-refractory prostate cancer after previous docetaxel chemotherapy. Clinical Genitourinary Cancer 6 134-137. (doi:10.3816/CGC. 2008.n.023)

Steinbild S, Mross K, Frost A, Morant R, Gillessen S, Dittrich C, Strumberg D, Hochhaus A, Hanauske AR, Edler L et al. 2007 A clinical phase II study with sorafenib in patients with progressive hormone-refractory prostate cancer: a study of the CESAR Central European Society for Anticancer Drug Research - EWIV. British Journal of Cancer 97 1480-1485. (doi:10.1038/sj.bjc.6604064)

Tannock IF, de Wit R, Berry WR, Horti J, Pluzanska A, Chi KN, Oudard S, Theodore C, James ND, Turesson I et al. 2004 Docetaxel plus prednisone or mitoxantrone plus prednisone for advanced prostate cancer. New England Journal of Medicine 351 1502-1512. (doi:10.1056/NEJMoa040720)

Tepper CG, Boucher DL, Ryan PE, Ma AH, Xia L, Lee LF, Pretlow TG \& Kung HJ 2002 Characterization of a novel androgen receptor mutation in a relapsed CWR22 prostate cancer xenograft and cell line. Cancer Research 62 6606-6614.

Tran C, Ouk S, Clegg NJ, Chen Y, Watson PA, Arora V, Wongvipat J, Smith-Jones PM, Yoo D, Kwon A et al. 2009 Development of a second-generation antiandrogen for treatment of advanced prostate cancer. Science $\mathbf{3 2 4}$ 787-790. (doi:10.1126/science.1168175)

Ullen A, Farnebo M, Thyrell L, Mahmoudi S, Kharaziha P, Lennartsson L, Grander D, Panaretakis T \& Nilsson S 2010 Sorafenib induces apoptosis and autophagy in prostate cancer cells in vitro. International Journal of Oncology 37 15-20. (doi:10.3892/ijo_00000648)

Ulivi P, Arienti C, Zoli W, Scarsella M, Carloni S, Fabbri F, Tesei A, Chiadini E, Orlandi A, Passeri D et al. 2010 In vitro and in vivo antitumor efficacy of docetaxel and sorafenib combination in human pancreatic cancer cells. Current Cancer Drug Targets 10 600-610. (doi:10.2174/ 156800910791859489)

Visakorpi T, Hyytinen E, Koivisto P, Tanner M, Keinanen R, Palmberg C, Palotie A, Tammela T, Isola J \& Kallioniemi OP 1995 In vivo amplification of the androgen receptor gene and progression of human prostate cancer. Nature Genetics 9 401-406. (doi:10.1038/ng0495-401)

Vlietstra RJ, van Alewijk DC, Hermans KG, van Steenbrugge GJ \& Trapman J 1998 Frequent inactivation of PTEN in prostate cancer cell lines and xenografts. Cancer Research $\mathbf{5 8}$ 2720-2723.

Wei G, Wang M, Hyslop T, Wang Z \& Carr BI 2010 Vitamin K enhancement of sorafenib-mediated HCC cell growth inhibition in vitro and in vivo. International Journal of Cancer 127 2949-2958. (doi:10.1002/ ijc.25498) 
Wilhelm SM, Carter C, Tang L, Wilkie D, McNabola A, Rong H, Chen C, Zhang X, Vincent P, McHugh M et al. 2004 BAY 43-9006 exhibits broad spectrum oral antitumor activity and targets the RAF/MEK/ERK pathway and receptor tyrosine kinases involved in tumor progression and angiogenesis. Cancer Research 64 7099-7109. (doi:10.1158/0008-5472.CAN-04-1443)

Yadav A, Kumar B, Teknos TN \& Kumar P 2011 Sorafenib enhances the antitumor effects of chemoradiation treatment by downregulating ERCC-1 and XRCC-1 DNA repair proteins. Molecular Cancer Therapeutics 10 1241-1251. (doi:10.1158/1535-7163. MCT-11-0004)

Yu C, Bruzek A, Meng XW, Gores GJ, Carter CA, Kaufmann SH \& Adjei AA 2005 The role of Mcl-1 downregulation in the proapoptotic activity of the multikinase inhibitor BAY 43-9006. Oncogene 24 6861-6869. (doi:10.1038/sj. onc.1208841)

Zemskova M, Sahakian E, Bashkirova S \& Lilly M 2008 The PIM1 kinase is a critical component of a survival pathway activated by docetaxel and promotes survival of docetaxel-treated prostate cancer cells. Journal of Biological Chemistry 283 20635-20644. (doi:10.1074/jbc. M709479200)

Received in final form 15 February 2012 Accepted 24 February 2012 Made available online as an Accepted Preprint 1 March 2012 